\title{
Integrity Management and Policy in Italy
}

\author{
Elio Borgonovi* ${ }^{*}$ Paolo Esposito**
}

\begin{abstract}
Low efficiency of public administrations is considered an obstacle towards overcoming the effects of the financial crisis and recovering growth. Why does this happen? It is for sure because principles, criteria, techniques of good management are not tailored to the peculiarity of public interest organizations, but also because public integrity distortions orient people to use it as an instrument to exercise power. New Public Management has not been sufficient to break the vicious circle of inefficient public administration and a new anti-corruption law has been introduced in Italy. Its main objective is to prevent and control "the negative corruption effect" attempts towards the common good - also characterized by capital rationing - which can compromise the present and future wealth of communities.
\end{abstract}

Keywords: New Public Management; Public Integrity; Corruption; Rules; Accounting Regulation; Transparency; Public Administration; Global Markets

\section{From New Public Management to Public Integrity Management}

The financial crisis that broke up in 2008 - even though some early signs had already been spotted in 2007 - was mainly analysed with regards to the relationship between financial and real, brick-and-mortar economy, the role of market and state intervention (in terms of government bail-outs of banks, real estate investing institutions, automotives and other enterprises in strategic sectors). Policies to restore public finance balance, to reduce or at least not to increase public debt, to favour the economic recovery, to avoid some countries' defaults in order to defend the Euro and the world economy have been discussed both at national and at supranational level (European Union, Euro Group, G8, G20, IMF, World Bank). Inadequate attention was given, on the other hand, to the impact of hidden or even criminal economy on legal or legitimate economy.

As a hidden, shady economy grows, it becomes harder and harder to support economic growth and social development through adequate public policies.

In this context the public sector has the goal and the responsibility to promote social sustainability in order to facilitate growth and development, taking into account all stakeholders' requirements, in one word to pursue public interest. The Italian critical situation is due to many factors: a rigid labour market, a vast

\footnotetext{
* Full Professor of Public Management, Bocconi University (elio.borgonovi@unibocconi.it)

** Assistant Professor of Business Administration, Sannio University (paolo.esposito@ unisannio.it)
} 
majority of SME that are not able to face and tackle global competition, a high public debt and, consequently, a high amount of interests to be paid, a fragmented financial system, as well as a political system where parties in power sometimes operate only to favour specific interests, so that they become accountable to people willing to use corruption (Senior, 2006) and bribery to achieve their goals (Pepe, Mushagalusa Nshombo, Risso, 2014; Del Monte, Papagni, 2007; Chien, 2008; Cepiku, 2002, 2004; Borgonovi, 2002; Broadman, Recanatini, 2000; Kaufmann, 1998; Borgonovi, Giavazzi, 1994; World Bank, 2006a).

In order to overcome the (ab)use of power, organizational, reporting and anticorruption models (Esposito, Ricci, 2015), may be helpful to monitor, prevent, control and report the phenomenon of corruption alteration, integrity distortion (Lasthuizen, Huberts, Heres, 2011) and State capture, both in service delivery and regulatory functions (Schick, 2003).

The main questions the present paper tries to answer can be summarized as follows:

- What is the impact of corruption and crime on the Italian economy?

- What are the measures of the new anti-corruption law in Italy?

The paper proposes a conceptual framework (deductive approach) and an analysis of the Italian anti-corruption law (inductive approach).

\section{Methodological Process}

The research is based on a literature review about integrity distorsions (corruption, tax evasion, ab-use of power) and New Public Management (from now on NPM) theories on management applied to public administration (Kickert, 2004; Hughes Owen, 2003; Pierre, 1955; Mussari, 1994; Hood, 1991; Hood, Jackson, 1991; James, Kenneth, 1983), useful to investigate the variables and the dimensions producing State Capture and corruption in the Italian case.

Corruption is characterized by obscure and confused borders in the same dimensional definition and measurement (linked to the index of perceived corruption). So, starting from a literature review, this study is based on data published by Transparency International.

The analysis of corruption level achieved by some Italian local governments in crisis, is measured on the responses to a semi-structured questionnaire by councilors and public managers, looking at understanding the potential link between good governance practices and a suitable accountability system able to improve citizens' and stakeholders' participation and loyalty (Borgonovi, 2007). The paper aims at measuring political commitment in order to undertake responsible policies and involve stakeholders into strategic decision-making processes ruling out client and patronage behaviors.

Through a questionnaire, the paper analyzes which are the key factors in defining political accountability and how transparent and efficient public governance models might improve government performance in managing public resources, in providing public services and in getting better inter-governmental relationship. The work also provides a critical perspective on accountability and limits of transparency as this can be viewed as the first stage of a largest research stream on the possible methods of assessing accountability (Ricci, 2016). 


\section{Literature Review}

Literature defines integrity as the quality of acting in accordance with relevant moral values, norms (Raine, Keasy, 2012) or rules (Lasthuizen, Huberts, Heres, 2011; Shah, 2007). Lack of integrity or distortion in politicians' and public officials' behavior causes the condition of State capture: actions of individuals, lobbies, companies, in both the private and public sector, that may influence the enactment of laws, regulations, decrees and other government policies to their advantage through illicit and non-transparent provision of benefits to public officials (Jain, 2001; Broadman, Recanatini, 2000; Kaufmann,1998). The World Bank (2000), defines State capture as the tendency by some elites, firms and groups of power and/or interest, to illegally contribute to the formation of laws, policies and regulations of the State. Hellmann (2002), defines State capture as group of companies' efforts to contribute to the design and approval of laws, policies, and regulations of the State, to their advantage, by providing illicit private gains to the officials, to maintain public order. Broadman and Recanatini (2001) define State Capture as a form of corruption that is particularly harmful in the ability of companies to subvert the entire political process to ensure that policies and regulations favorable to their interests are enabled or captured. In the World Bank Transition Report (2000) on the analysis of "anti-corruption" measures, a distinction is made between State capture and administrative corruption. The latter is defined as an intentional distortion (Broadman and Recanatini, 2000) in implementing laws, rules and regulations as a result of illegal and non-transparent provision of personal benefits to public officials. In addition, the report points out the way politicians and state officials may either promote or be subjected to corruption. The authoritative body Transparency International defines corruption as "abuse of entrusted power for private benefit", either material or not, linked to political and/or professional ambitions (Whilhelm, 2002).

The aim of corruption is to allow undeserved advantages to stakeholders, producing loss or destruction of public value (Esposito and Ricci, 2014, 2015) . The economist Ian Senior (2006) underlined a further aspect of corruption, as he argued that there is corruption "when a briber secretly does a favor to a corrupted or an appointed person, in order to influence some actions that may benefit both the corruptor and the appointed person, and on which the corrupted has authority".

The World Bank Report also propose a taxonomy of institutions being captured (executive, legislative, judicial system, independent regulatory agencies), type of capturer (private companies, interest groups, political leaders), and type of benefits provided to public officials (money bribes, in-kind gifts, shares or property rights in companies and businesses). Capture through corruption may also occur beyond the borders of the State by companies and foreign investors or by foreign governments (Pashev, 2011; Kaufmann, 1998).

Among several corruptive phenomena (legal, business-based, political, legislative, etc.), OECD identifies a clear distinction between corruption, State capture, abuse of office, lobbying activities and conflict of interests (OECD, 2013). Furthermore, OECD identifies a set of causes that interdependently contribute to produce the phenomenon of corruption and State capture (Cepiku, 2002, 2004): i) inadequate compliance with accounting and reporting procedures, $i i$ ) weakness of 
internal and external control systems, iii) legitimate appointment of unprofessional people, iiii) lobbying and funding activities aimed at substituting private to general interest, iiiii) weakness of public guarantees for contracts. However, as corruption is a complex and difficult issue to investigate, researchers, academics or organizations dealing with it have different points of view on the issue. Actually, there are many disciplinary perspectives (in the fields of macroeconomics, political science, sociology, public management, business management, business ethics, law and administrative law), that can be considered more inductive and descriptive in North America, UK and Northern Europe, and more deductive and normative in Germany, France, Italy and Southern Europe in general.

Until recent years, economics and managerial studies showed inadequate interest in corruption. These disciplines were much more oriented to understand the physiological behavior of enterprises, markets, economic systems rather than their pathological aspects. Economics and management theories were defined with the aim of enhancing an efficient functioning of economic systems, enterprises and public institutions (Pepe, Mushagalusa Nshombo, Risso, 2014; Brondoni, Pepe, 2007; Brondoni, 2003). Corruption was considered mainly an effect of anthropological, ethical and moral attitudes.

In the past two decades, however, it has become clearer and clearer that weaknesses and even failures in economic development and international cooperation, the increase in public deficits and debts in many developed countries, the financial crisis, the bankruptcy of companies and banks have been all either caused or boosted by corruption (Esposito and Ricci, 2017a). Shady or illegitimate flows of money generated by corruption, as well as by rackets and drugs deal, cause distortion in international trade, financial transactions, public works, international tenders and market functioning in general. Corruption affects the market creating deviance, malformation, deformation and degeneration (Lewis, 2008; Golden, Picci, 2005; Jain, 2001). Therefore, economic ethics and business ethics have become a more and more relevant issue for research and teaching in the fields of economics and management. One can therefore say that corruption is an informal economic process that generates hidden costs in the market transaction, in particular with regard to business government relations (because of alterations in politicians' and public officials' integrity). This process leads to: $i$ ) private profits and benefits to the detriment of the public community; ii) State capture and Society capture; iii) competition distortions, hindering economic growth. This is how corruption becomes a systemic failure of the legal and legitimate economy.

\section{Economic Development and Institutions}

Economic development theories underline a negative relation between underdevelopment and corruption of public bodies (both central and local governments), that is confirmed by many empirical researches and evidence-based analyses (World Bank, 2006a, 2007). The higher the corruption, the lower the development or, as in the case of developed countries, the lower the GDP increase. This is at the same time a direct and indirect consequence of the impact of corruption on the legal environment weakening, public administration inefficiency and unfair or distorted competition. Broadman and Recanatini's explanation is 
appreciable from a theoretical point of view (see below the adapted formula), but it reveals perhaps a lack of empirical robustness in some of the institutional indices that are likely to be endogenous to corruption: if it is true that low quality of government, weak institutions, low level of real democracy, low trade/GDP ratio may clear the way for corruption, it is also true that the diffusion of corruption prevents the strengthening of legal context and public administration reforms, creating a vicious circle.

Figure 1: Formula for corruption

Corruption $=f$ (quality of government, quality of political institutions, openness to trade $)=B 1+B 2($ Institutional indicators $)+B 3($ Index of democracy $)+B 4$ (Trade marks, plans, system index Corruption $=f$ (quality of governance, quality of political institutions, openness to trade $)=B 1+B 2$ (institutional indicators $)+$ B3 (democracy index) + B4 (Trade Marks, design and index systems)

Source: Broadman \& Recanatini, 2000.

Several programmes of the World Bank, IMF, Regional Development Bank and bilateral or multilateral agreements for economic development did not achieve the expected results (according to a macroeconomic model) because of government corruption. For this reason, in the last 10-15 years a chapter on institutional building was introduced in all dossiers that refer to international agreements on economic development and financial stability (World Bank, 2013). National responses involve fighting corruption, whereas regional integration is seen as a way of introducing external pressure towards drawing better policies. This implies going beyond the trade agenda into deeper issues of policy reform. The question would then become whether peer pressure at regional level can bring about responsive national institutions to global challenges. "Answering this question is more likely to provide policy makers with a handle on how to bring about the positive interaction, rather than simply liberalizing their economic regimes in the hope that the appropriate institutional change will materialize". (OECD working paper n.181-How globalization improves Governance, November 2001).

Data on perceived corruption in the last three years (Transparency International NGO Ranking) show that economic underdevelopment or low economic growth rate are also a consequence of the impact of corruption on the competitiveness of enterprises and the overall economy. Furthermore, World Bank economic studies show that the investment rate increases when the incidence of corruption decreases: by recovering two points in a hypothetical corruption scale from 10 to 1 (from low to high incidence), the investment rate/GDP would grow at least by $4 \%$ while per capita GDP would increase at least by $0.5 \%$ per year. "Confirming available results in the literature, a detectable significant direct effect from trade policy is not measured; however reducing trade barriers may still bring positive corruption reductions in the long run. More open economies, enjoying more foreign competition and investing abundantly in institution building, will normally register lower corruption levels." (OECD working paper n.181-How globalization improves Governance, November 2001).

In Italy, some institutions and independent researchers and think tanks (Italian Central Bank, Treasury Department, Finance Ministry, Italian Statistical Institute 
and others) estimate that corruption reaches 70 billion Euros, around $4.5 \%$ of GDP, that is a relevant part of the hidden economy estimated in 150 billion Euros, around 9.4\% of GDP. Even if corruption is a general phenomenon in society, Public Administration can be considered its privileged place, especially with regard to public procurement of goods and services, planning permissions, trade licenses and permits, credit-granting or subsidized loans to private enterprises. It is clear that the Country's economic recovery may be facilitated by an effective policy to reduce corruption. This is a requirement to attract foreign investments that nowadays are also constrained by lengthy bureaucratic procedures.

\section{From New Public Management (NPM) to Public Integrity Management (PIM)}

The New Public Management, or simply management applied to public administration, as it is in Italian Economia Aziendale or german Betriebswirtschaftslehre, is undoubtedly an advancement in comparison to the bureaucratic model. Actually, it enables to deal not only with sovereign functions for which legal and formal criteria are prevalent, but also with functions for which economic and social criteria are relevant or prevalent (Esposito, Borgonovi, 2014). Nevertheless, it shows more than one weakness in an increasingly multicultural, pluralistic and fragmented society, in which the involvement of many subjects is needed to reach common objectives. So the government governance and the system governance frameworks have been developed.

But the main problem that bureaucratic, New Public Management, government governance models cannot solve is the pathological degeneration of public administration that has been considered, or has been characterized, as a means to exercise power by authoritarian governments or representative bodies (politicians), who pursue particular instead of general interests. This degeneration has determined the phenomenon defined as state capture, that happens when visible or invisible lobbies, and often organized crime, infiltrate administrations as well as political bodies. A wider vicious circle arises because by infiltrating the public administration, interest groups (and criminality) can condition the whole of society (society capture). This phenomenon has so far been studied in relation with transition economies (Kaufmann, 1998).

The main consequences of this degeneration can be summarized as follows:

1. Progressive loss of compliance with the law (e.g. substantial and increasingly weakening of attention, also in a formal sense) and weakening of the attention and consideration towards the public interest and the common good;

2. Progressive delegitimization of public institutions in both the political (e.g. elected bodies, political parties) and the technical/professional component (e.g. employees and public officials);

3. Low levels of functionality and productivity of the public administration, in turn causing an increase of costs for citizens, families, businesses, other economic and social activities and reducing development and competitiveness rates for the whole country;

4. Permeability of the public administration, especially in public procurement processes, to the interference of politics (or politicians), to the pressure of interest 
groups (establishments) that hinder the modernization process, to the infiltration of groups of obscure power (freemasonry of any kind) and organized crime, and to the spread of corruption (bribery);

5. Distortion in the processes of recruitment and career development of personnel, that are not implemented on the basis of merit and professionalism.

Anyway, it should be clear by now that it is inappropriate to consider public administration as a great and homogeneous Molok. The public system is in fact composed by thousands of public administrations, such as an economic sector is composed by thousands of enterprises. Some of them are characterized by high levels of functionality, effectiveness, efficiency, productivity, while others display in a more or less extensive way the negative phenomena mentioned above.

During the past three decades Italy has been marked by efforts to introduce a managerial approach in public institutions at central, regional and local level. Consistently with the Italian approach to management (Economia Aziendale) similar but not completely equivalent to NPM - principles, criteria and techniques of:

- administrative productivity and efficiency;

- expenditure containment and cost control;

- quality of services;

- effectiveness and efficacy of policies;

- economic sustainability;

- formal procedure simplification;

- clients-citizens orientation;

became more and more popular in the scientific world and have been experimented in advanced public institutions. Italian Economia Aziendale is rooted in Continental Europe's institutionalist theory and approach, while NMP is rooted in North America's and the UK's scientific management theory and approach. Nevertheless, the transition from a bureaucratic to a managerial model was unsuccessful for many reasons: worsening of the political arena and adverse selection of elected administrators, weakening of public institution credibility, prevailing of individual interest on public interest, inadequate managerial education, both in junior and executive managers.

Managerial culture and techniques also proved ineffective in tackling Mafia illegitimate economy. Something more is needed, and that can be achieved through the transition from management to accountability, that means openness in public procurement and personal recruitment procedures, easy accessibility to public documents, urban planning and other strategic choices, government decisionmaking processes, disclosure of accounting and social reporting to all citizens.

\section{Accountability and Integrity Management in the Public Sector}

Accountability has been conceptualized in terms of responsibility - ensuring that officials (and extensively also private managers) are responsible for respecting the law or code of ethics (Bovens, 1999). The concept of accountability emphasizes the role of external actors in enforcing the respect of laws and codes of conduct (Ricci, 2016). A stronger citizens' voice generates incentives for public officials to budget and deliver services of the quality and quantity expected by their clients. Only 
accountability can strengthen the voice influence when the exit solution (as it happens in the market) is not available. The concept of responsibility relies more on public servants' internalized values and understanding of the law and of appropriate behaviour. Such a standard of personal responsibility may be acceptable and enforceable in countries with strong and credible public institutions, but this approach may be risky when the level of agreement on behavioural standards is low. On the other hand, in terms of responsiveness, accountability system is closely related to civil servants' willingness to really serve citizens rather than to pursue their own interest. This concept refers to the many pressures that impinge on public servants' behaviour and the expected difficulties they face when making choices.

Integrity Management in the Public Sector can improve the internal functioning of Public Administration and govern formal economic and social relationships but only society, meaning pressure exerted by citizens, can remove or at least reduce corruption and its connection with crime. The hope is that the transition from accounting and government to accountability and system governance paradigm, that implies the involvement of many public and private economic and social bodies, could be more successful in fighting crime and corruption, not only in increasing economic growth. Eradicating or minimizing corruption and crime is a prerequisite for economic growth and sustainability. A better accountability and governance system could break the vicious circle around political consensus. Indeed, accountability (that enables to recognize merits and professionalism and to evaluate Public Administration's performances) can reduce the level of patronage, that connects public managers and employees to political parties and organized crime. The "vicious circle" leads to Public Performance deterioration, due to political pressure to manipulate public resources in order to pursue hidden agendas.

The accountability approach helps redefine spoils system models in order to ensure independence and accountability in the recruitment and appointment of public managers. Moreover, it facilitates performance assessments for public employees and top managers, this way guaranteeing the provision of incentives or penalties according to the performance achieved.

Accountability also reduces the misuse of the announcement effect, that arises when politicians try to get consensus by announcing some programs or actions that are not concretely implemented. As accountability is related to actual results, the negative connection between organized crime and political consensus is broken. Managerial and accountability reforms and the efforts to fight organized crime, poor political game, inefficiency and waste of resources have been so far unsuccessful in Italy, particularly in the Southern regions (Esposito, Borgonovi, 2014).

\section{Administrative and Anti-Corruption Legislations}

The conceptual framework concerning the issue of anti-corruption legislation is analyzed in different countries. In France "The offences of corruption are set out in the Criminal Code. The offences of corruption in relation to foreign public officials (Law of 30 June 2000) and corruption in relation to private individuals (Law of 4 July 2005) were recently added to the offences of corruption in relation to public officials in the French legislation. Both passive and active corruption fall within the 
scope of the legislation". In Germany "The principal corruption offences (Straftaten) concerning public officials (Amtsträger) are defined in ss. 331 et seq. of the Criminal Code (Strafgesetzbuch ("StGB")). Further legislation - the European Bribery Act (EU-Bestechungsgesetz, "EUBest $\left.G^{\prime \prime}\right)$ and the International Bribery Act (Gesetz, zur Bekämpfung internationaler Bestechung, "IntBestG") - has extended the scope of the offences". In the UK "The Bribery Act 2010 creates statutory offences of bribing and being bribed. It is due to be brought into force in April 2011. Until then the Prevention of Corruption Acts 1889-1916 are still the applicable law. The Bribery Act offences of bribing another person are set out in Section 1.... The offences of bribing and being bribed apply equally to bribery in the public and the private sector. Section 6 of the Bribery Act sets out a separate offence of bribing a foreign public official.". In the U.S. "It is a crime under US law to bribe both domestic and non-US government officials, and to engage in private commercial bribery. Bribery, however, falls under several distinct federal and state criminal statutes. In general, the prohibited conduct involves paying, offering, attempting or promising to pay, public officials improperly to influence their official acts, or, in the private context, causing an employee or agent to act in a way contrary to the interests of their employer. US law also generally recognizes the concept of aiding and abetting a violation and conspiring to engage in violative conduct as separate criminal offences." The United Nations Convention against corruption, signed by 140 countries, states that "The purposes of the Convention, stated at Article 1, are: to promote and strengthen measures to prevent and combat corruption more efficiently and effectively; to promote, facilitate and support international cooperation and technical assistance in the prevention of and fight against corruption, including in asset recovery; to promote integrity, accountability and proper management of public affairs and public property. All Parties to the Convention are required to criminalize: the bribery of national and foreign public officials, as well as officials of public international organizations; the embezzlement, misappropriation or other diversion of either public or private funds by a public official to whom the funds have been entrusted; the laundering of proceeds of crime; and obstruction of justice. In addition Parties must consider criminalizing trading in influence, the abuse of functions by a public official, illicit enrichment and private sector bribery". The OECD Convention on Combating Bribery of Foreign Public Officials in International Business Transactions, signed by 38 countries, states that "The Convention requires Parties to make the bribery of foreign public officials (as defined) a criminal offence, as well as related offences of incitement, aiding and abetting, authorization, attempt and conspiracy. Parties must also (in accordance with their legal principles) establish the liability of legal persons for the bribery of foreign public officials, and must put in place effective penalties, including seizure and confiscation or comparable monetary sanctions."

A new anti-corruption tool useful to tackle corruption is also the ISO 37001 standard, published on October 15, 2016, called Anti-bribery management systems Requirements with guidance for use. ISO 37001 identifies a new management standard to help organizations in the fight against corruption, by establishing a culture of integrity, transparency and compliance.

The regulation can be used alone or in conjunction with other management system regulations (ISO 9001, ISO 14001, ISO / IEC 27001, ISO 19600) and other management regulations (ISO 26000, ISO 31000). ISO 37001 does not specifically 
address fraud, cartels and other anti-trust/competition offences, money-laundering or other activities related to corrupt practices, although an organization can choose to extend the scope of the management system to include such activities. ISO 37001 defines requirements and provides a guideline to help an organization, coping or preventing corruption in addition to comply with anti-corruption legislation, establishing a link between two different cultures: that of management systems and that of organizational models and anti-corruption plans.

These examples of legislation, agreements, standards and conventions are a clear signal of awareness all around the world of the danger that the connection among crime, corruption, politics, public administration and private businesses can bring to legal economies and sustainable development.

\section{Italy's Anti-Corruption Law: Rethinking Public Integrity Review}

In Italy, the first attempt to fight crime and corruption is the Rognoni-La Torre law (1983), which was passed to fight organized crime. The enactment of this law swung between success and failure, but was not effective enough in stopping corruption. Only seizure (confiscation) of Mafia assets and their donation to nonprofit organizations and social enterprises positively reduces Mafia's economic power, so that is becoming an increasingly successful strategy to fight corruption (Esposito, Borgonovi, 2014). In March 2010, after many political scandals and cases involving corrupt politicians and officials, the Italian Government submitted a law proposal against corruption to the Parliament. Surprisingly, this proposal was approved only two years later. It is interesting to stress how, if one considers the number of Google reports, there are only 45.200 entries regarding the law proposal and 1.880.000 entries regarding the decree over the period March 2010 - January 2012. The evidence shows a misleading effect: most of Italian citizens were convinced that the law had already been enacted (decree), while it was at that time only a proposal (decree proposal) to be discussed and approved.

In response to the ongoing economic crisis, Italy is undertaking a series of critically important reforms, combining pro-growth policies with severe austerity measures to achieve fiscal consolidation. The success of these structural reforms will rely heavily on the capacity of the government to restore trust in its ability and commitment to guide the country towards sustainable growth. In order to restore the deficit of trust in the Italian government, the public sector needs to be embedded within a comprehensive integrity framework. Law 190 of November 6, 2012 (the Anti-Corruption Law) firmly establishes the notion of public sector integrity management and strengthens existing corruption prevention provisions through the designation of a new anti-corruption authority, a detailed framework for the adoption of a national anti-corruption plan, and new provisions regarding the conduct and prevention of conflict of interests in the public sector (OECD, 2013, 2017).

Italy has adopted a new Anti-Corruption Law: Law n .190 dated 6 November 2012, which was published in the Italian Official Gazette on 13 November. Bribery and corruption costs the Italian economy an estimated 60 billion Euros per year. The new Law is set to combat that figure and bring the Italian anticorruption legislation in line with that of other EU countries. We look at the provisions of the 
new Law - its impact on both the public and the private sector and on Law 231/2001 regarding administrative liability of companies - and make proposals on actions to be taken.

The anti-corruption law requires each Public Administration to put in place specific measures to prevent the occurrence of acts of corruption or bribery. These include:

- the adoption of an anti-corruption plan;

- the appointment of a compliance officer;

- the adoption of a code of conduct for employees.

A new national anti-corruption authority will be established. Each Public Administration must implement its own anti-corruption plan on the basis of this National Anti-Corruption Plan and use their own plan as a continuous assessment tool to check their level of exposure to bribery risks. The plan must identify all activities that entail a degree of risk and set out what arrangements have been made (or will be made) to prevent the occurrence of corruption in these areas. The compliance officer in each Public Administration will monitor how well the plan is being implemented, assess its sustainability over time and amend it to make sure that it complies with any changes in anti-corruption legislation or in the Public Administration's own activities or operational model.

Provisions have also been made for whistle-blowing procedures. Public employees who report acts of misconduct in the workplace will not suffer dismissal, sanctions or discrimination as a result of their action. Each Public Administration will adopt an internal mechanism to protect any whistleblower and will keep their identity secret, unless she or he has given prior consent to its disclosure.

\section{Private sector}

The Anti-Corruption Law defines three new corruption and bribery offences that are relevant for the private sector. The three new offences are: induced bribery, dealings in unlawful influences and private bribery, which can be defined as follows:

\section{Induced bribery}

It is an offence for a public officer or a person charged with a public service, abusing of his or her powers or office, to induce a private party to give or promise money or any other advantage. The private party who is unlawfully induced to give or promise such money or other advantage to the public officer or person charged with a public office also commits an offence.

Article 319-quater of the Italian Criminal Code

\section{Dealings in unlawful influences}

It is an offence for a person to take advantage of his or her relationship with a public officer for the purpose of receiving or promising money or other kind of economic advantage as compensation in exchange for his or her unlawful mediation. It is also an offence for any person to unlawfully give or promise money or other advantage in exchange for unlawful mediation.

Article 346-bis of the Italian Criminal Code

\section{Private bribery}

It is an offence for a manager, general executive, director, auditor and liquidator of a company (or any employee of a company acting under the direction or supervision of any of these persons) to act - or omit to act - in breach of the duties 
relating to their office or in breach of the duty of loyalty incumbent upon them, to the detriment of the company, in exchange for the payment or the promise of money or other kind of advantage. It is also an offence for any person to give or promise money or other advantage to these individuals.

Article 2635 of the Italian Civil Code

\section{Administrative liability}

Italian Law 231/2001 provides that companies acting in Italy may be held liable, fined, subject to restraining orders prohibiting the exercise of business, and/or subject to confiscation orders if certain offences - including corruption, bribery, fraud, money laundering offences - are committed, or attempted, in the interest of the company, by company officers, managers or their subordinates, or by third parties acting on behalf of the company, such as agents, suppliers or other partners. The company's liability is considered in addition to the criminal liability of the person who committed the offences.

Law 231/2001 applies to all types of Italian companies and associations and, according to consolidated case law and legal doctrine, also to companies with registered office(s) abroad, operating in Italy through a branch.

Consequently, an act of bribery or corruption, including private bribery, committed by any employee or third party acting on behalf of the company could result in criminal liability for the individual that committed the offence as well as in administrative liability for the company under Law 231/2001.

As to private bribery, only those companies that de facto bribe other companies will be held liable under the provisions of Law 231/2001. Since no sanction is provided for the companies that are bribed, the latter have no legal incentive to implement any procedure to combat receiving bribes.

\section{Protection against liability}

The Anti-Corruption Law encourages all companies to adopt an organisational model that will afford protection against liability. Awareness of the importance of combating bribery and corruption, as well as other financial crimes such as money laundering and fraud, is increasing at all levels across Italy. Now, more than ever, involvement in an act of corruption or bribery may have serious negative legal and financial consequences. This may take the form of fines amounting to millions of euros; it may involve the prohibition of further business activity in Italy; and quite certainly it will damage a company's reputation.

Under article 6 of Law 231/2001, a company may be able to build an effective defense case and therefore be exempted from administrative liability if it can prove that:

- it has implemented an organisational model aimed at preventing the criminal offence allegedly committed;

- it has appointed an internal supervising and control body (organismo di vigilanza), with independent powers of action and control, responsible for the supervision, implementation, effectiveness and compliance of the organisational model;

- the officer, manager (or other subordinate) of the company that committed or attempted to commit the offence, have fraudulently evaded the protections put in place by the company through its organisational model.

- Moreover, the company must prove that it has: 
- assessed all business activities in relation to which crimes may be committed and the kind of offences that could be committed;

- designed and implemented procedures, policies and protocols aimed at preventing offences of the kind to which the company is exposed;

- introduced a sanctioning regime in the event of failure to comply with provisions set out in the organisational model and relevant procedures and protocols;

- made provisions for adequate training programmes for staff and senior management.

\section{Conclusive Remarks}

The phenomenon of corruption, crime and bribery infiltration in the economy and in particular in the public sector has been studied by several sociologists, anthropologists, political scientists, while economists and management scholars showed little interest until recently. In the past decade, national legislation in many countries and agreements and conventions involving international and supranational organizations have been adopted. Nevertheless, the enactment was poor or unsatisfactory.

The phenomenon strangled the economic growth in Italy, in particular in southern regions with a more marked Mafia presence. It has recently also hit some northern regions. Special legislation to fight organized crime and therefore to reduce corruption and crime, was introduced in 1983 but it can be considered widely unsuccessful. The attempt to enact this legislation and to break the vicious circle involving Mafia, politics and shady business caused a real war, where dozens of faithful civil servants (Giorgio Ambrosoli, Giovanni Falcone and Paolo Borsellino are the most well-known cases) were murdered.

The introduction of NPM, according to the Italian model of Economia Aziendale, did not achieve the desired effects of increasing productivity and efficiency, downsizing the public sector, improving the quality of public services, increasing transparency of actions taken by public managers, and reducing the black economy related to crime, bribery and corruption.

Therefore, the authors are convinced that only a wide participation of citizens and their empowerment through a public accountability and governance system can give chances to effectively fight crime and corruption. Cultural and social changes are the keystones to strengthen legal economy and to fight the illegitimate and illegal one. Ethical culture (Brondoni, 2003; Brondoni, Pepe, 2007) and ethical behaviour require going beyond mere professionalism in order to reject proposals and policies which are idealistic or impractical. Ethical behavior requires not only developing technical skills such as macro-economic or public finance know-how, but also strengthening negotiating skills, communicating properly and pushing through unpopular choices. Ethical behavior requires overcoming the resistance to change, through the ability to develop proposals aimed at implementing win-win strategies. 


\section{Bibliography}

Borgonovi E., (2002), “Corruzione: fenomeno sociale non della PA”, Azienda pubblica,. 2002, vol. 15 , n. 6, pp. 583-589

Borgonovi E., Giavazzi C., (1994), Ethics and efficiency in the modern state. Are they in conflict?, Milano, Egea.

Borgonovi, E. (2007). Sustainable Economic Growth in the Global Society, Symphonya. Emerging Issues in Management (symphonya.unimib.it), 2, 50-63.

http://dx.doi.org/10.4468/2007.2.06borgonovi

Broadman, H. G., Recanatini G., (2000), Seeds of Corruption: Do Market Institutions Matter? World Bank Policy Research Working Paper No. 2368.

Brondoni, S.M. (2003). Network Culture, Performance \& Corporate Responsibility, Symphonya Emerging Issues in Management (symphonya.unimib.it), 1, 8-24. http://dx.doi.org/10.4468/2003.1.02brondoni

Brondoni, S.M. \& Pepe, C. (2007). Overture de Ethics in Global Supply Chains, Symphonya Emerging Issues in Management (symphonya.unimib.it), 1, 1-4. http://dx.doi.org/10.4468/2007.2.01ouverture

Cepiku D., (2002), “The Challenge of corruption for Albanian Public Administration and business”, International Public Management Network Conference (IPMN), June 26-28, University of Siena.

Cepiku D., (2004), "Coping with corruption in Albanian public administration and business", in The International Public Management Review, Vol. 5, No. 1, pp. 99 - 137.

Chien, K., (2008), Quake damage tied to corruption - expert. Thomson Reuters

Del Monte A., Papagni E., (2007), The determinants of corruption in Italy; regional panel data analysis, European J. Political Economy, vol.23, pp.379-396.

Esposito P., (2010), State Capture, Governance, Accountability nelle aziende e nelle amministrazioni pubblico locali. Dallo State Capture alla Society Capture, RIREA, Roma.

Esposito P., Borgonovi E., (2014), Rethinking Pubic Integrity Review in Italy, Academy of Management Journal (AOM) Proceedings, Florida, Us.

Esposito P., Ricci P., (2017a), Corporate Social Responsibility, Global Encyclopedia of Public Administration, Public Policy, and Governance, Springer International Publishing, Springer International Publishing Switzerland.

Esposito P., Ricci P., (2015), How to turn Public (dis)Value into new Public Value? Evidence from Italy, Public Money \& Management,Vol. 1/2015, Taylor \& Francis.

Esposito P., Ricci P., (2014), Public (dis)Value: A case study, in Public Value Management, Measurement and Reporting (in J. Guthrie, G. Marcon, S. Russo, F. Farneti), Emerald Group Publishing.

Golden, M., Picci L., (2005), Proposals for a new measure of corruption, illustrated with Italian data. Economics and Politics 17(1): 37-75.

Hood C., Jackson M. W., (1991), Administrative argument, Dartmouth: Aldershot.

Hughes Owen E., (2003), Public Management and Administration. An introduction, third edition, New York: Palgrave Macmillan.

Jain, A.K., (2001), Corruption: a review, J. Econ. Surveys, vol.15, pp.71-121

James P., Kenneth K. (1983), Public Management: Public and Private Perspectives, Mayfield Publishing Company.

Kaufmann, D., (1998), in The Political Economy of Corruption (ed. Jain, A. K.) Ch. 7 (Academic, 1998).

Kickert W. J. M., (2004), Distinctiveness of the Study of Public Management in France, Germany and Italy, IRSPM VIII Conference, Budapest.

Lasthuizen K., Huberts L., Heres L., (2011), How to measure integrity violations, Public Management Review, Routledge, Edinburgh. 
Mussari R., (1994), "Public sector financial management reform in Italy”, in Guthrie J. et al. (eds), International public financial management reform: progress, contradictions, and challenges, Information Age Publishing Inc.

OECD, (2013), OECD Integrity Review of Italy.

OECD, (2017), OECD Pubic Sector Integrity- A framework for assessment.

Pashev K. (2011), Corruption and accession, Public Management Review, Routledge, Edinburgh.

Pepe C., Mushagalusa Nshombo J.M., Risso M., (2014), Preventing Corruption in Africa: Emerging Challenges in the Mining Sector of the Democratic Republic of Congo, Symphnonya Emerging Issues in Management, n. 2, 2014.

Pierre J. (1995), Bureaucracy in the modern State: an introduction to comparative public administration, Bath: Bookcraft.

Raine JW., Keasey P., (2012), From Police Authorities to Police \& Crime Commissioners: Might policing become more publicly accountable?, Emerald, UK.

Ricci P., (2016), Accountability, in Global Encyclopedia of Public Administration, Public Policy and Governance, Springer International Publishing, Switzerland. Senior I., (2006), Corruption - the World's Big C: Cases, Causes, Consequences, Cures, The Institute of Economic Affairs in association with Profile Books, London.

Schick A., (2003), The performing State: reflection on an idea whose time has come but whose implementation has not, OECD Journal on Budgeting.

Shah A., (2007), Performance accountability and combating corruption, Washington, DC: The Work Bank.

Transparency international, (2016), Corruption Perceptions Index (2010); available at go.nature.com/.

Wilhelm, P.G,. (2002), International validation of the Corruption Perceptions Index: implications for business ethics and entrepreneurship, Journ. Business Ethics. Vol.35, pp.177-188.

World Bank, (2006a), Strengthening Bank Group Engagement on Governance and Anti-Corruption, Washington, DC: World Bank (17 August).

World Bank, (2007), Global Monitoring Report 2006. Washington, DC: World Bank.

World Bank, (2013), World Development Indicators.Washington, DC: World Bank. 